\title{
Experiencing mobbing at workplace facing psychological gender and occupational burnout
}

Anna Góralewska-Słońska, Ph.D., University of Zielona Góra, Faculty of Education, Psychology and Sociology, Poland, ORCID: 0000-0003-3797-301X.

\section{Introduction}

The interest in the problem of mobbing has not ceased for several decades, nowadays mobbing has become one of the most serious psycho-social hazards in the work environment, both scientists and practitioners in the field of organization and management, or psychology, sociology and law do not cease in their efforts to learn this threatening phenomenon and find a way to reduce it and create a safe working environment. The work "The mobbing and psychological terror at workplaces" (Leymann, 1990) has been a source of intense research interest in the harassment of employees. Mobbing is a heterogeneous phenomenon, so it is necessary to look at its different approaches. Leymann (1996) describes mobbing as a "psychic terror used in work, which engages hostile attitude and unethical communication, systematically supported by one or several people in relation to another, which in turn pushes the victim to a position that prevents its effective defence; This situation occurs very often (at least once a week) and for a long period (at least for half a year) (Chomczyński, 2008, p. 68). Characterizing moral harassment, Hirigoyen (2003) also points out that the core 
of the destructive nature of mobbing is that psychic violence is administered in such minimal doses that each of them is difficult to capture separately, while the combined effect of cyclicality and frequency of attacks is dangerous. On the basis of the analysis of the definition of mobbing (Einarsen, Hoel, Zapf, Cooper, 2011; Leymann, 1996; Sojka, Walczuk, 2015; Warszewska-Makuch, 2005; Zapf, Einarsen, 2001) it is possible to distinguish repetitive features characterizing mobbing, which were also separated and described by LutgenSandvik, Namie and Namie (2009) as the distinctive features of mobbing, these are: repeatability, durability, escalation, imbalance of strength, damage, hostile organizational environment, attributed purposefulness of actions and communication problems. The classification of mobbing activities carried out by Leymann (1990) is sometimes treated as a base, because he presented 45 detailed criteria, features - which are used to identify mobbing. These features have been included in five groups, creating activities, each successive group is more and more escalated towards the overwhelming and drastic harassment and terrorization of employees: beginning with activities disorganizing the victim's communication process, through actions that disrupt social relations, or actions aimed at destroying, degradation of the victim's image and actions that lead to lowering the professional position of the victim, to actions that result in physical and mental health problems victims (Leymann, 1990).

\section{The experience of mobbing - an analysis of previous research}

Reports on mobbing research are not consistent in terms of the size of the phenomenon, Warszewska - Makuch (2008) speaks of $10 \%$ of mobbing in the teacher environment, while in the Polish population of employees - $25 \%$ of workers are victims of mobbing (Durniat, 2009; Miedzik, 2008 ). Macko (2016) notes that the use of various methods of measuring mobbing leads to a situation of inconsistent results related to the scale of mobbing in Poland, where the risk of mobbing may be from 6 to $25 \%$ of employees. Differences in the scale of the phenomenon may result, among others, from the fact that "mobbing" can be variously defined, and thus differently operationalized for the usefulness of scientific research. An important reason may also be the subjectivity of experiencing the situation of mobbing by the respondents, whose perception is influenced by many factors. On the basis of literature and empirical studies, the repetitive conditions of mobbing were distinguished, which can be systematized as four main groups of determinants (Góralewska-Słońska, 2016): socio-economic factors, factors related to the characteristics of the perpetrator,

ANNA GÓRALEWSKA-SŁOŃSKA 
factors related to traits of the victim and organizational factors. It should be noted that the number of factors determining mobbing is impressive. It seems interesting that numerous studies on mobbing indicate the biological sex as one of many factors that can determine that a person will be subjected to mobbing. The results of research carried out by Drabek and Merecz (2013) showed that women were more vulnerable to mobbing, more often than men experienced mobbing behaviour, in particular actions that affected their social relationships, as well as their image. Empirical evidence related to the greater exposure of women to mobbing activities is also confirmed by studies conducted by Salin (2001, 2015), Cortina and the team (2001), Simpson and Cohen (2004). Reliability, however, requires the addition of studies that emphasize the lack of differences between women and men as victims of mobbing (Einarsen, Skogstad, 1996; Hoel, Cooper, 2000; Leymann, 1996; Ortega, Høgh, Pejtersen, Feveile, Olsen, 2009) Vartia, 1996, Vartia, Hyyti, 2002), there are also studies in which men are the sex that is more intensely experiencing mobbing (Eriksen, Einarsen, 2004). Lack of unambiguity of the results obtained, concerning biological sex as a cause of the occurrence of mobbing, allows to ask a lot of questions: are the gender of a mobber or gender structure in the organization important? Or maybe another factor - so far unexplored in the context of mobbing characterizing the potential victim of mobbing - psychological gender? It is inspiring to discover what has not yet been discovered with full awareness of the researcher that this is just the beginning of a new direction of research.

\section{Selected factors related to mobbing}

\subsection{Psychological Gender}

Psychological gender can be "determined by a sense of belonging to a given gender, and the identification process manifests itself (...) through behaviour falling within the scope of gender roles, as well as through experiences or feelings associated with them" (Brzezińska, Appelt, Ziółkowska, 2008, p. 225). According to Bem (2000), gender should be considered at least in two categories: (1) sex (biological) is associated with primary, secondary, tertiary sexual characteristics that determine the individual's characteristics, (2) psychological, socio-cultural gender is associated with properties that have been acquired - culturally attributed to gender, that is, roles, attitudes and social behaviour. The basis of the concept of the psychological gender is the theory of gender patterns (Gender Schema Theory) by Bem (2000). Important for Bem's (1982) psychological gender

\footnotetext{
Experiencing mobbing at workplace facing
} psychological gender and occupational 
theory is the assumption that the psychological gender reflects the tendency to use gender stereotypes characteristic of a particular culture in the selfidentification process, and not the actual characteristics of a person. Typically masculine or typically female features - will be the source of psychological gender content. Scientific research shows that despite cultural differences, certain characteristics and values are attributed to women - establishing bonds, a need for respect, and other men - strength, aggression, a need for success, domination and autonomy (Best, Williams, 2002). Konopka (2011) indicates that gender-specific persons function in a specific direction - men in the causative direction and women in the direction of the community. The studies by Mandal (2000) show a stereotypical image of a traditional woman (sensitive, caring) and a modern woman - confident, aggressive and ambitious, while a modern man should be sensitive, delicate and focused on caring for his own appearance, in contrast to a traditional man who, according to Arcimowicz (2003), is dominant and independent.

Due to discrepancies in the results and conclusions from previous research projects, it is not possible to give an unambiguous answer to the question: Does biological sex determine mobbing? This led to a research question: Can psychological gender be associated with mobbing? Similarly as in the case of biological sex, there are inconsistent results indicating that victim's personality traits may increase their susceptibility to experiencing mobbing, however, researchers agree that the responsible factor may be a person's traits as higher susceptibility to injury, it is also important how the person experiences and interprets negative behaviours, which may have rooting in the functions of cognitive and emotional processes conditioned by the personality (Matthiesen, Einarsen 2001, McFarlane 1989, Bowman 1999). Sensitivity and emotionality are traditionally attributed to the dimension of femininity, so it is possible to get to know the relationship of femininity and increased susceptibility to mobbing. The goal of the researcher is to look for a relationship between the psychological gender and mobbing, an indication of whether such a relationship exists. In the search for answers, the hypotheses were adopted: The first hypothesis adopted the following form: The more the character is characterized by female features the more likely he/she is to experience mobbing, the second hy pothesis, however, is: The more the person is characterized by masculine features, the less likely he/ she is to experience mobbing. The analysis of the literature on the subject and the results of the cited studies concerning the nature of mobbing also allowed noticing that there is a connection between mobbing and burnout, professional burnout and the sex of the burned person. Guided by these results, research 
has formulated the second goal, the essence of which is to check whether the psychological sex may be related to burnout and what is the direction of this relationship?

\subsection{Occupational burnout}

Occupational burnout is a "psychological syndrome of emotional exhaustion, depersonalization and a reduced sense of personal achievement that can occur in people working with other people in a certain way" (Maslach, 2009, p. 15). This definition is part of a three-component model of occupational burnout: (I stage) emotional exhaustion - is associated with the feeling that the person is emotionally overburdened and that his or her emotional resources have been weakened; (II stage) depersonalization - refers to a negative, cynical and indifferent reaction to the needs of other people who are recipients of help; (III stage) reduced sense of personal achievements - the essence is the lack of measurable achievements and a significant sense of devaluation of the value of activities performed (Maslach, 2009). And Litzke and Schuh (2007) note that occupational burnout "is not a consequence of sporadic traumatic events, but rather a slow mental extermination" (p. 167) and this is not an isolated view. According to Sęk (2009), an important factor for the development of burnout is the lack of success in coping with stressful situations, then the conviction that it is impossible to effectively deal with difficulties in a professional life, the situations that particularly generate stress at work is the experience of mobbing. Maslach, Schaufeli and Leiter (2001) also see the sources of occupational burnout in the mismatch between the individual and their conditions and requirements posed by work. Other sources of burnout may be environmental factors (e.g. inadequate leadership, conflict and ambiguity of the role, lack of gratification) and personality (naivety, idealism, aspirations, external location of control) (Burisch, 2009). Kulik (2008) notes that occupational burnout is a process that can be seen as a continuum from passing through and experiencing professional stress, until a full-blown burnout. Referring to the presented concepts, it can be noticed that mobbing as an active, chronic stressor with a high severity may be related to burnout. Research on occupational burnout shows its relationship with mobbing (Giorgi et al 2016, Mościcka-Teske, Drabek, Pyżalski, 2014, Sá, Fleming, 2008, Stanisławska et al., 2015), it is also important that occupational burnout is also with aid occupations (Maslach, 2009, Pines, Aronson, 1988), which are often performed by people with a high level of need to care for others, sensitivities, emotional competences that are necessary in performing assistance

Experiencing mobbing at workplace facing psychological gender and occupational 
professions and features that are stereotypically assigned to women. Maybe it is worth checking if the experience of mobbing is related to burnout? and whether the dimension of the psychological gender - femininity will be associated with burnout? Obtaining the answer to the question about the relationship between mobbing and occupational burnout will enable verification of the third hypothesis, which adopted the following form: The more the person experiences mobbing, the more he/she is exposed to burnout.

\section{Method}

Participants of the study. 187 people took part in the study, of which 7 were excluded due to significant data gaps. In the end, the group consisted of 180 people, of which $68,3 \%$ were women $(N=123)$ and $31,7 \%$ men $(N=57)$ in the age from 20 to 57 years $(M=27,30 ; S D=7,79)$. The study participants were full-time and part-time students studying at one of the universities, in the following fields: Psychology - 30\% ( $N=54)$, Management $-23,3 \%(N=42)$, Logistics $-20 \%(N=$ $36)$, Economics $-14,4 \%(N=26)$ and Management and production engineering $-12,2 \%(N=22)$. The research was carried out in the second half of 2017. The participants of the study were employed people with at least one-year work experience in the same place of work.

Research tools:

1. Negative Actions Questionnaire - NAQ, the Polish adaptation of the NAQ questionnaire (Einarsen, Raknes, Matthiesen, Hellesøy 1994, Einarsen, Raknes, 1997, Einarsen, Hoel 2001 after Warszewska-Makuch, 2007) by Warszewska-Makuch (2007) is used to measure mobbing in workplace. The questionnaire enables the identification and measurement of the level of exposure to mobbing in the work environment. The internal coefficient of a-Cronbach's for the Polish scale is 0,94 , which proves the high reliability of the tool, and the questionnaire is characterized by theoretical accuracy (Warszewska-Makuch, 2007).

2. Inventory for Psychological Gender Assessment - IPP, used for Psychological Sexual Identification IPP was developed by Kuczyńska (1992). It consists of 35 items, 15 statements illustrating the stereotype of femininity - Femininity Scale, 15 statements characterized by the stereotype of masculinity - Masculinity Scale and 5 statements are buffer statements, the features that make up them are neutral. Levels of femininity and masculinity result from the number of points declared by the respondents on each scale. The questionnaire allows the assessment of the degree to which the individual creating the concept of 
oneself identifies with the cultural definition of femininity and/or masculinity. Reliability coefficients for individual scales are: Masculinity Scale $r_{t t}=0,78$, and Femininity Scale $\mathrm{r}_{\mathrm{tt}}=0,79$ (Kuczyńska, 2012).

3. Pattern of behaviours and work-related experiences - AVEM, developed in 1996 by Schaarschmidt and Fischer (1996 for: Rongińska, Gajda, 2012) in the Polish adaptation of Rongińska and Gajda (2012) is used to determine individual resources in terms of dealing with the requirements of professional situations. The structure of the questionnaire includes three spheres of workrelated personality: First sphere - Occupational engagement, second sphere - Mental resilience and strategies to combat problem situations and the third sphere - Emotional approach to work - eleven scales depicts behaviour and survival in a work situation, and each scale is described by six statements (Rongińska, Gajda, 2012). Reliability measured by a-Cronbach for different scales assumes for the Polish version values from 0,71 to 0,84, the SpearmanBrown correlation coefficient for different scales assumes values from 0,70 to 0,83 for the Polish version (Rongińska, Gajda, 2012).

\section{Analysis and interpretation of research results}

The analysis of the obtained results starts with the presentation of the properties of the variables under investigation. The following statistical description refers to the results obtained in the negative action questionnaire (sum), omitting question 23 (constituting a subjective opinion of the respondents on the subject of mobbing) and the sum of the results obtained in the measurement of femininity, masculinity, as well as the distribution of the predicted affiliation to a specific type of behaviour and work-related experiences (Type G, Type S, Type of Risk A, Type of Risk B). The obtained descriptive statistics are presented in table 1.

Table 1. Descriptive statistics of variables used in the analysis of research results

\begin{tabular}{l|c|c|c|c|c}
\hline & N & Minimum & Maximum & Average & $\begin{array}{c}\text { Standard } \\
\text { deviation }\end{array}$ \\
\hline NAQ (intensity of negative actions) & 171 & 22.00 & 93.00 & 36.93 & 14.33 \\
\hline Masculinity & 180 & 29.00 & 68.00 & 51.87 & 7.46 \\
\hline Femininity & 180 & 35.00 & 71.00 & 54.18 & 7.16 \\
\hline Type G (healthy) & 180 & 0.00 & 0.98 & 0.24 & 0.31
\end{tabular}

Experiencing mobbing at workplace facing psychological gender and occupational 


\begin{tabular}{l|c|c|c|c|c}
\hline Type S (economical) & 180 & 0.00 & 1.00 & 0.27 & 0.34 \\
\hline Type A (overloaded) & 180 & 0.00 & 1.00 & 0.23 & 0.31 \\
\hline Type B (burned out) & 180 & 0.00 & 1.00 & 0.26 & 0.33 \\
\hline
\end{tabular}

Source: own study

To assess the strength and nature of relationships between variables, the analysis of $r$-Pearson's correlation was performed, the results of which are presented in table 2 .

Table 2. Values of r-Pearson correlation coefficients between variables used in the analysis of research results

\begin{tabular}{l|c|c|c|c|c|c|c}
\hline & NAQ & $\begin{array}{c}\text { Mascu- } \\
\text { linity }\end{array}$ & $\begin{array}{c}\text { Femi- } \\
\text { ninity }\end{array}$ & Type G & Type S & Type A & Type B \\
\hline $\begin{array}{l}\text { (NAQ) (intensity of nega- } \\
\text { tive actions) }\end{array}$ & 1 & 0.145 & -0.037 & $-0.161^{*}$ & -0.122 & 0.118 & $0.159^{*}$ \\
\hline Masculinity & 0.145 & 1 & -0.069 & $0.171^{*}$ & -0.068 & 0.081 & $-0.164^{*}$ \\
\hline Femininity & -0.037 & -0.069 & 1 & 0.011 & $-0.156^{*}$ & -0.029 & $0.175^{*}$ \\
\hline Type G (healthy) & $-0.161^{*}$ & $0.171^{*}$ & 0.011 & 1 & $-0.199^{* *}$ & $-0.235^{* *}$ & $-0.494^{* *}$ \\
\hline Type S (economical) & -0.122 & -0.068 & $-0.156^{*}$ & $-0.199^{* *}$ & 1 & $-0.513^{* *}$ & $-0.350^{* *}$ \\
\hline Type A (overloaded) & 0.118 & 0.081 & -0.029 & $-0.235^{* *}$ & $-0.513^{* *}$ & 1 & $-0.204^{* *}$ \\
\hline Type B (burned out) & $0.159^{*}$ & $-0.164^{*}$ & $0.175^{*}$ & $-0.494^{* *}$ & $-0.350^{* *}$ & $-0.204^{* *}$ & 1 \\
\hline
\end{tabular}

The analysis of $r$-Pearson's correlation, which made it possible to check the existence of relations between variables, showed several statistically significant interdependencies. The results indicate a negative and low relationship between negative actions (experiencing mobbing) and masculinity, but only at the level of statistical tendency $(p=0,058)$. There are moderate negative correlations between type $\mathrm{G}$ of (healthy) behaviours and work-related experiences and risk type $B$ (burned out), as well as between type $S$ (economical) and risk type A (overloaded). 
In order to understand the relationship of mobbing (negative actions) with the psychological gender, two hypotheses were put forward, the verification of which was to enable the answer to the research question: Is there a relationship between mobbing and psychological gender? To verify the first hypothesis, which assumed that: the more a person is characterized by female traits, the more the mobbing can be experienced, the analysis of $r$-Pearson's correlation was carried out, showing no significant relationships $(r=-0,037 ; p=0,634)$, which requires the rejection of the adopted assumption. With reference to the second hypothesis, assuming that: the more the person is characterized by masculine features, to a lesser extent may experience mobbing, the analysis of $r$-Pearson's correlation was also used, which did not show any statistically significant relationships $(r=0,145 ; p=0,058)$, which also requires the rejection of the adopted assumption.

The answer to the research question about the relationship between mobbing and burnout was possible through verification of the third hypothesis, which assumed that: the more the person experiences mobbing, the more he/she is exposed to burnout - that is, he/she will represent behaviour and workrelated experiences characteristic of type B risk (burned out). The analysis of the $r$-Pearson correlation $(r=0,159 ; p=0,037)$, carried out in order to check the assumed assumption, showed a positive and low relationship between the variables. As the experience of mobbing increases, the risk of occupational burnout increases. The results of the analysis do not allow for the assumed assumption. Furthermore, the result of the analysis of research results indicates a negative correlation between mobbing and type $G$ (healthy) behaviours and work-related experiences $(r=-0,161 ; p=0,036)$ also does not allow the hypothesis to be rejected. Along with the increase in mobbing experiences, the level of behaviours and experiences related to G type of work (healthy) decreases. Thus, it can be concluded that there is a connection between mobbing and burnout. In addition, an attempt was also made to find the answer to the question: what are the determinants of burnout? To answer this question, multivariate linear regression analysis was performed. The explanatory variable was occupational burnout (represented by risk type B (burned out), as turned on variable predictors studying: experience of mobbing (NAQ), level of femininity and masculinity (IPP) - table 3. The proposed regression model allows for better reasoning than average, $F(3,167)$ $=5,313 ; p=0,002$ and explains seven percent of the variance of the dependent variable (matching $\mathrm{R}^{2}=0,07$ ).

Experiencing mobbing at workplace facing psychological gender and occupational 
Table 3. Values of standardized beta coefficients together with significance tests for predictors within the linear regression model

\begin{tabular}{l|c|c|c}
\hline Predictors & Beta & $\mathbf{t}$ & Significance \\
\hline NAQ & 0.192 & 2.562 & 0.011 \\
\hline Masculinity & -0.181 & -2.416 & 0.017 \\
\hline Femininity & 0.157 & 2.114 & 0.036 \\
\hline
\end{tabular}

Dependent variable: risk type B (burned out)

Source: own study

The analysis of the results showed that along with the increase in the level on the scale of femininity, the level of exposure to occupational burnout increases. On the other hand, in the case of the masculinity scale, the situation is reversed, i.e. the increase in the level of masculine features affects the reduction of the risk of burnout. Also mobbing turns out to be a good predictor, which is consistent with the previous analysis of results. Increasing the experience of mobbing contributes to an increased level of exposure to occupational burnout.

\section{Discussion of research results}

The search for the answer to the question about the relationship between experiencing mobbing and psychological gender was inspired by research on the relationship between gender and mobbing, the results of which have been mentioned before are not clear. Therefore, it was decided to check whether the characteristics of a given sex, not biological sex, are an element determining mobbing. It may be more feminine or more masculine that the mobbing experience will be more or less intense for each dimension. The results of own research do not confirm the relationship between the dimensions of the psychological gender, femininity, masculinity and the experience of mobbing. The relationship between the experience of mobbing and femininity could not be demonstrated, whereas the marginal relationship between masculinity and the experience of mobbing exists at the level of statistical tendency. Probably obtaining such research results was the effect of the specifics of the group of participants, 33,3\% of androgynous individuals were included among the examined persons, while simultaneously obtaining elevated results on the scale 
of femininity and masculinity (46 women and $14 \mathrm{men}$ ), 34,4\% of people who scored higher on the masculinity scale (thirty-five men and twenty-seven male women) and $18,3 \%$ of those who scored higher on the femininity scale (thirtyone female women and two female men) and $13,9 \%$ of indeterminate people, achieving low scores on the scale of femininity and masculinity (nineteen women and six men). It seems that the obtained research results partially confirm the new stereotype of the woman who is to be aggressive, ambitious and self-confident (Kwiatkowska, 1999, Mandal, 2000), because these features stereotype the man and shape the dimension of masculinity. Similar results were obtained in the research of persons on managerial positions, both women and men simultaneously had high intensity of female and male characteristics, and $15 \%$ of women represented male psychological gender, which may mean that women in managerial positions assume the roles assigned stereotypically to men (Lipowski et al. 2009).

Research on the subject of occupational burnout shows the relationship between burnout and mobbing (Giorgi et al., 2016, Mościcka-Teske, Drabek, Pyżalski, 2014, Sá, Fleming, 2008, Stanisławska et al. 2015) indicating that people experiencing mobbing are more predisposed to professional burnout, they experience deeper emotional exhaustion than people who do not experience negative actions. In order to check whether such a relationship exists, a hypothesis has been put forward that a person experiencing mobbing will be in the risk group associated with the possibility of being burned out professionally. The hypothesis was confirmed, as it turned out that people experiencing mobbing are exposed to occupational burnout - they represent Type B (burned out) behaviours and work-related experiences, and the G type representation (healthy) is inversely proportional. The experience of mobbing may be a predictor of burnout, which is consistent with the previous analysis of the results. This means that experiencing negative actions may be a reason for increasing the level of exposure to occupational burnout. In Maslach (2009) and Pines and Aronson (1988) studies, it is emphasized that professional burnout mainly affects people who perform support activities (occupations), these activities are most of ten performed by women. Among all respondents, as many as $23 \%$ of respondents represent type $\mathrm{B}$ risk burned out, of which $71,43 \%$ of people are women (biological sex), and $28,54 \%$ of people are men (biological sex), which confirms the results of research by other authors who write that women are more likely than men to be burned out (Kowalska, Bugajska, Żołnierczyk-Zreda 2010). The results obtained in own research and the conducted regression analysis confirmed the significance of the considered variables as predictors of burnout. The dimensions of the

Experiencing mobbing at workplace facing psychological gender and occupational 
psychological gender, including the increase on the scale of femininity and the decrease on the scale of masculinity and the increase in the experience of negative actions (mobbing) increases the risk of burnout, remembering that the specificity of the research group does not authorize to generalize the results of research on the entire population.

An important result of the research is that mobbing experiences have become the share of respondents, which confirms that despite the study of people potentially at risk of mobbing, the problem of experiencing negative actions exists, however, it should not be associated with the psychological gender of the subjects in the group of students surveyed.

It is also necessary to point out the problematic aspect of own research, which is that the participants of the research are potential victims of mobbing, not people who identify themselves as victims of violence at work, therefore, one should not generalize the conclusions from the research into the population of employees - victims of mobbing, but only refer to the group being examined. Another limitation of the conducted research is the specifics of the examined group - the examined persons do not constitute a representative group.

In the future, information that would deepen knowledge about the experience of mobbing could be obtained by conducting longitudinal studies in a work environment whose employees (even individuals) seek help in anti-mobbing associations, because there is a risk that other people employed in these organizations may also be vulnerable to experiencing mobbing - however, access to people seeking help identifying themselves as victims of mobbing is significantly hampered due to the negative psychological effects of mobbing, people experiencing mobbing do not want to return to traumatic situations, it becomes problematic to get their consent to participate in the research.

\section{Conclusions}

Summing up, it can be stated that conducting research on mobbing should be directed at identifying factors that determine the emergence of mobbing and foster its development. Knowing the predictors of mobbing should consequently enable to design an ideal organizational environment, free from these factors. It is necessary to focus on researching factors that can be shaped in the process of work organization, enabling the creation of secure organizations. Understanding the disposable conditions on the side of the victim and the aggressor is equally important, but much more difficult in terms of thinking about the anti-bullying policy. Longitudinal studies of 
specific work environments about which the researcher has knowledge that they may be at risk of mobbing, will enable to understand the nature of the phenomenon in terms of cause and effect. Questionnaire surveys (self-report), then longitudinal studies of a specific work environment seem to be a prelude to a reliable understanding of the mobbing nature and determinants. By far the most effective research method would be participative observation, which would allow learning the nature of mobbing in a specific work environment - however, this is a task that also requires courage and commitment from conscious managers who care about a safe working environment. Another method of studying mobbing could be case analysis, however, it has limited application in the situation of a large population study, allowing only illustrating extreme cases of mobbing phenomenon. It would also be appropriate to conduct research in a work environment free of mobbing to check what factors on the human side (characteristics of superiors, subordinates) and the working environment shape the climate of the organization in which employees work in an atmosphere free from the pathology of mobbing.

\section{Summary}

\section{Experiencing mobbing at workplace facing psychological gen- der and occupational burnout}

The problem of mobbing in the work environment is significant, there are many factors determining mobbing, and its negative effects affect both the employees of the organization and their social environment as well as the work process. The aim of this study is to determine the relationship of experiencing mobbing with psychological gender dimensions and occupational burnout. 180 people participated in the study, a group of respondents consisted of 123 women and 57 men, aged 20 to 57 years. The research process used: Negative Action Questionnaire (NAQ), Psychological Gender Inventory (IPP) and Questionnaire to study behaviours and experiences related to work (AVEM).

In order to analyse the obtained research results, a correlation analysis was performed to check the relationship between experiencing mobbing activities, (1) and the psychological gender and (2) burnout as well as a linear regression analysis to check what predictors of burnout are. The results of statistical analyses revealed that there is no connection between the experience of mobbing and the psychological gender dimension - femininity, 
while it was noticed that at the level of statistical tendency there is the relationship between the experience of mobbing and the psychological gender dimension - masculinity. Analysing the results obtained, it was noticed that there is a connection between the experience of mobbing and burnout, people experiencing mobbing are at risk of occupational burnout.

Keywords: mobbing, occupational burnout, psychological gender.

\section{Streszczenie}

\section{Doświadczanie mobbingu $\mathbf{w}$ pracy a płeć psychologiczna i wypalenie zawodowe}

Problem mobbingu $\mathrm{w}$ środowisku pracy jest znaczący, istnieje wiele czynników determinujących mobbing, a jego negatywne skutki dotyczą zarówno pracowników organizacji i ich społecznego otoczenia jak i procesu pracy. Celem niniejszego opracowania jest określenie związków doświadczania mobbingu z wymiarami płci psychologicznej i wypaleniem zawodowym. W badaniu uczestniczyło 180 osób, grupę respondentów stanowiło 123 kobiety i 57 mężczyzn, w wieku od 20 do 57 lat. W procesie badawczym wykorzystano: Kwestionariusz Działań Negatywnych (NAQ), Inwentarz do Oceny Płci Psychologicznej (IPP) oraz Kwestionariusz do badania zachowań i przeżyć z związanych z pracą (AVEM).

W celu przeanalizowania uzyskanych wyników badań wykonano analizę korelacji $\mathrm{w}$ celu sprawdzenia związków pomiędzy doświadczaniem działań mobbingowych, (1) a płcią psychologiczną i (2) wypaleniem zawodowym oraz wykonano analizę regresji liniowej, aby sprawdzić jakie są predyktory wypalenia zawodowego. Wyniki analiz statystycznych ujawniły że nie ma związku pomiędzy doświadczaniem mobbingu a wymiarem płci psychologicznej - kobiecość, natomiast dostrzeżono, że na poziomie tendencji statystycznej jest związek pomiędzy doświadczeniem mobbingu a wymiarem płci psychologicznej - męskością. Analizując otrzymane wyniki, dostrzeżono, że istnieje związek pomiędzy doświadczaniem mobbingu a wypaleniem zawodowym, osoby doświadczające mobbingu są zagrożone wypaleniem zawodowym. 


\section{Słowa}

kluczowe: mobbing, wypalenie zawodowe, płeć psychologiczna.

JEL

Classification: M12

\section{References}

1. Arcimowicz, K. (2003). Obraz mężczyzny w polskich mediach. Prawda, fatsz, stereotyp. Gdańsk: Gdańskie Wydawnictwo Psychologiczne.

2. Bem, S. (1982). Gender Schema Theory and Self-Schema Theory Compared: A Comment on Markus, Crane, Bernstein, and Siladi's "Self-Schemas and Gender". Journal of Personality and Social Psychology, 43(6), 1192-1194.

3. Bem, S. (2000). Męskość-kobiecość. O różnicach wynikających z ptci. Gdańsk: Gdańskie Wydawnictwo Psychologiczne.

4. Best, D., Williams, J. (2002). Perspektywa międzykulturowa. In: B. Wojciszke (ed.), Kobiety i mężczyźni: odmienne spojrzenie na różnice (pp. 118145). Gdańsk: Gdańskie Wydawnictwo Psychologiczne.

5. Brzezińska A., Appelt K., Ziółkowska B. (2008). Psychologia rozwoju człowieka, In: J. Strelau, D. Doliński (ed.), Psychologia akademicka, Vol. 2 (pp. 95-290). Gdańsk: Gdańskie Wydawnictwo Psychologiczne.

6. Burisch, M. (2009). W poszukiwaniu teorii - przemyślenia na temat natury i etiologii wypalenia. In: H. Sęk (ed.), Wypalenie zawodowe. Przyczyny i zapobieganie (pp. 58-83). Warszawa: Wydawnictwo Naukowe PWN.

7. Chomczyński, P. (2008). Mobbing w pracy z perspektywy interakcyjnej. Proces stawania się ofiarą. Łódź: Wydawnictwo Uniwersytetu Łódzkiego.

8. Bowman, L. (1999). Individual differences in posttraumatic distress: Problems with the DSM IV model., Canadian Journal of Psychiatry, 44, 21-33.

9. Durniat, K. (2009). Mobbing jako patologia organizacji i zarządzania - doniesienia z badań własnych. In: S. Banaszak i K. Doktór (ed.), Socjologiczne, pedagogiczne i psychologiczne problem organizacji i zarzadzania (pp. 377-391). Poznań: WSKiZ.

10. Einarsen, S., Raknes, B., Matthiesen, S. (1994). Bullying and harassment at work and their relationships to work environment quality: An exploratory study. European Work and Organizational Psychology, 4, 381-401.

11. Einarsen, S., Skogstad A. (1996). Bullying at work - Epidemiological findings in public and private organizations. European Journal of Work and Organizational Psychology, 5(2), 185-201. DOI: 10.1080/13594329608414854.

12. Einarsen, S., Raknes, B. (1997). Harassment in the workplace and the victimization of men. Violence and Victims, 12, 247-263.

13. Einarsen, S., Hoel, H., Zapf, D., Cooper, C. (2011). The concept of bullying and harassment at work: The European tradition. In: S. Einarsen, $\mathrm{H}$. 
Hoel, D. Zapf, C. Cooper (ed.), Bullying and harassment in the workplace: Developments in theory, research, and practice (pp. 3-40). Boca Raton, London, New York: Taylor \& Francis Press.

14. Eriksen W, Einarsen S. (2004). Gender minority as a risk factor of exposure to bullying at work - The case of male assistant nurses. European Journal of Work and Organizational Psychology, 13(4), 473-492. DOI: 10.1080/13594320444000173

15. Freudenberger, H., Richelson G. (1980). Burnout : The High Cost of High Achievement, Garden City, N.Y: Doubleday

16. Giorgi, G., Mancuso, S., Fiz Perez, F., Castiello D'Antonio, A., Mucci, N., Cupelli, V., Arcangeli, G. (2016). Bullying among nurses and its relationship with burnout and organizational climate. International Journal of Nursing Practice, 22(2), 160-168. DOI: 10.1111/ijn.12376.

17. Góralewska-Słońska, A. (2016). Mobbing w środowisku pracy. Rys teoretyczny. RELACJE. Studia z nauk społecznych, 2, 2016 (61-74).

18. Hirigoyen, M. (2003). Molestowanie w pracy. Poznań: W Drodze.

19. Hoel, H., Cooper, C. (2000). Destructive conflict and bullying at work. Manchester: Manchester School of Management (UMIST).

20. Konopka K. (2011). Regulacyjne funkcje płci psychologicznej, Psychologia Jakości Życia, 10(2), 143-158.

21. Kowalska, M., Bugajska, J., Żołnierczyk-Zreda, D. (2010). Częstość występowania zespołu wypalenia zawodowego wśród pracowników biurowych. Medycyna Pracy, 61(6), 615-623.

22. Kuczyńska, A. (2012). Inwentarz do oceny ptci psychologicznej. Podręcznik, Warszawa: Pracownia Testów Psychologicznych PTP.

23. Kulik, M. (2008). Cierpienie, które przerasta czyli o wypaleniu lekarzy pracujących z ludźmi przewlekle chorymi. Studia z psychologii w Katolickim Uniwersytecie Lubelskim. 15, 81-112.

24. Kwiatkowska, A. (1999). Siła tradycji i pokusa zmiany, czyli o stereotypach płciowych. In: J. Miluska, i P. Boski (ed.), Męskość - kobiecość w perspektywie indywidualnej i kulturowej (pp. 143-172). Warszawa: Wyd. Naukowe PWN.

25. Leymann, H. (1990). Mobbing and psychological terror at workplaces. Violence and Victims, 5, 119-126.

26. Leymann, H. (1996). The content and development of mobbing at work. European Journal of Work and Organizational Psychology, 5 (2), 165-184.

27. Lipowski, M., Nieckarz, Z., Celińska, S., Konieczny, T. (2009). Zachowania narcystyczne a płeć psychologiczna menedżerów. Zeszyty Naukowe Wyższej Szkoły Administracji i Biznesu im E. Kwiatkowskiego w Gdyni, 11, 157-170.

28. Litzke S., Schuh H. (2007). Stres, mobbing i wypalenie zawodowe. Gdańsk: Gdańskie Wydawnictwo Psychologiczne.

29. Lutgen-Sandvik P., Namie,G., Namie, R. (2009). Workplace Bullying: Causes, Consequences, and Corrections. In: P. Lutgen-Sandvik i B. Sypher 
(ed.) Destructive Organizational Communication (pp. 27-53). New York: Routledge Press.

30. Mandal, E. (2000). Podmiotowe i interpersonalne konsekwencje stereotypów związanych z ptcia. Katowice: Wydawnictwo Uniwersytetu Śląskiego.

31. Maslach, Ch. (2009). Wypalenie w perspektywie wielowymiarowej. In: H. Sęk (ed.) Wypalenie zawodowe. Przyczyny i zapobieganie (pp. 13-32). Warszawa: Wydawnictwo Naukowe PWN.

32. McFarlane, A. (1989). The aetiology of posttraumatic morbidity: Predisposing, precipitating, and perpetuating

33. factors, British Journal of Psychiatry, 154:221-228.

34. Miedzik, M. (2008). Mobbing - charakterystyka zjawiska w Polsce. Polityka Społeczna, 3, 31-34.

35. Mościcka-Teske, A., Drabek, M., Pyżalski, J. (2014). Doświadczenie mobbingu i wrogich zachowań w miejscu pracy a występowanie objawów wypalenia zawodowego u nauczycieli. Medycyna Pracy, 65(4), 535-542.

36. Ortega, A., Høgh, A., Pejtersen, J., Feveile, H. Olsen O. (2009). Prevalence of workplace bullying and risk groups: A representative population study. International Archives of Occupational and Environmental Health, 82(6), 417-426. DOI: 10.1007/s00420-008-0339-8.

37. Pines A., Aronson, E.(1988). Career burnout: Causes and Cures, New York: Free Press.

38. Rongińska, T., Gajda, W. (2012). Strategie radzenia sobie z obciążeniem psychicznym w pracy zawodowej. Zielona Góra: Uniwersytet Zielonogórski.

39. Sá, L., Fleming, M. (2008). Bullying, burnout, and mental health amongst Portuguese nurses. Issues in Mental Health Nursing, 29(4), 411-426. DOI: 10.1080/01612840801904480.

40. Salin, D. (2001). Prevalence and forms of bullying among business professionals: a comparison of two different strategies for measuring bullying. European Journal of Work and Organizational Psychology, 10(4), 425441. DOI: $10.1080 / 13594320143000771$.

41. Salin, D. (2015). Risk factors of workplace bullying for men and women: The role of the psychosocial and physical work environment. Scandinavian Journal of Psychology. 56 (1), 69-77. DOI:10.1111/sjop.12169.

42. Schaufeli, W., Leiter M., Maslach Ch. (2009), Burnout: 35 years of research and practice, Career Development International, 14(3), 204-220.

43. Sęk, H. (2009). Uwarunkowania i mechanizmy wypalenia zawodowego w modelu społecznej psychologii poznawczej. In: H. Sęk (ed.), Wypalenie zawodowe. Przyczyny i zapobieganie (pp. 83-113). Warszawa: Wydawnictwo Naukowe PWN.

44. Simpson R, Cohen C. (2004). Dangerous Work: The Gendered Nature of Bullying in the Context of Higher Education. Gender, Work EOrganization, $11,(2), 163-186$. 
45. Sojka, W., Walczuk K. (2015). Mobbing - socjologiczno - prawny zarys zagadnienia. "Rocznik Administracji publicznej”. Nauka o administracji 1, 145-161.

46. Stanisławska, M., Siudowska, S., Jurczak, A., Grochans, E. (2015). Mobbing i wypalenie zawodowe $\mathrm{w}$ wybranych środowiskach pracy. Problemy pielegniarstwa, 23 (3), 367-37.

47. Vartia, M. (1996). The sources of bullying - psychological work environment and organizational climate. European Journal Work and Organizational Psychology, 5(2), 203-214. DOI: 10.1080/13594329608414855.

48. Vartia M., Hyyti J. (2002). Gender differences in workplace bullying among prison officers. European Journal Work and Organizational Psychology, 11(1), 113-126. DOI: 10.1080/13594320143000870.

49. Warszewska-Makuch, M. (2005). Mobbing w pracy-przyczyny i konsekwencje. Bezpieczeństwo Pracy, 3(404), 5-7.

50. Warszewska-Makuch, M. (2007). Polska adaptacja kwestionariusza NAQ do pomiaru mobbingu w miejscu pracy, Bezpieczeństwo Pracy, 4, 16-19.

51. Zapf, D., Einarsen, S. (2001). Bullying in the workplace: Recent trends in research and practice - An introduction. European Journal of Work and Organizational Psychology, 10 (4),369-373.DOI:10.1080/13594320143000807.

52. Zapf, D., Einarsen, S. (2011). Individual antecedents of bullying: Victims and perpetrators. In: S. Einarsen, H. Hoel, D. Zapf, C. Cooper (ed.), Bullying and harassment in the workplace: Developments in theory, research, and practice (pp. 177-200). Boca Raton London New York: CRC Press Taylor \&Francis Group. 